\title{
Surgical treatment of chronic complete acromioclavicular dislocation
}

Accepted: 30 September 2003 / Published online: 4 November 2003

(C) Springer-Verlag 2003

\begin{abstract}
We treated surgically 14 patients with symptomatic complete dislocation of the acromioclavicular joint. The surgical procedure included reconstruction of the coracoclavicular ligament using the coracoacromial ligament as substitute, reconstruction of the acromioclavicular ligament, and imbrications of the deltotrapezius aponeurosis over the top of the distal clavicle. A temporary tension band between the clavicle and acromion was used to stabilize the joint. Two patients were lost to follow-up. Twelve patients were followed for an average of 20 (18-60) months. Functional outcome was assessed according to modified UCLA acromioclavicular rating scale. The results were excellent in eight patients, good in three, and fair in one. In one patient, there was loosening of the temporary fixation with subluxation of the clavicle.
\end{abstract}

Résumé Nous avons traité chirurgicalement 14 malades présentant une luxation acromioclaviculaire complète. La technique chirurgicale a inclus la reconstruction du ligament coracoclaviculaire en utilisant le ligament coraco-acromial, la reconstruction du ligament acromioclaviculaire, et la fixation de l'aponévrose deltotrapezienne sur le sommet de la clavicule distale. Une fixation temporaire entre la clavicule et l'acromion a été utilisé pour se stabiliser l'articulation. Deux malades ont été perdus de vue. Douze malades ont été suivis en moyenne 20 (18-60) mois. Le résultat fonctionnel a été établi d'après le score acromioclaviculaire UCLA modifié. Les résultats étaient excellents pour huit malades, bon pour trois, et passable pour un. Dans un cas il y a eu échec de la fixation temporaire avec subluxation de la clavicule.

\footnotetext{
F. F. Adam · O. Farouk

Department of Orthopaedics, Assiut University Hospital,

Assiut, Egypt

F. F. Adam (๖)

Faculty of Medicine, Assiut University, Assiut, Egypt

e-mail: Adam_ffa@yahoo.com

Tel.: +2-088-312321

Fax: +2-088-333327
}

\section{Introduction}

There are several methods for treating complete acromioclavicular dislocations $[1,2,4,7]$. The aim of this study was to evaluate the results of our surgical procedure, which aimed at static and dynamic stabilization of the acromioclavicular joint.

\section{Material and methods}

Between 1994 and 2001, we treated 14 patients with symptomatic total dislocation of the acromioclavicular joint. Our inclusion criteria were: (1) adult patient, (2) complete acromioclavicular dislocation 3 months after injury or more, (3) persistent symptoms after conservative treatment or negligence, (4) no previous surgery, and (5) no coexisting glenohumeral arthritis, impingement or rotator cuff insufficiency. Two patients were lost, and the average follow-up for the remaining was $20(18-60)$ months. There were nine men and three women aged between 23 and 48 years. The time elapsed between trauma and surgery ranged from 3 to 11 months. The dominant shoulder was involved in nine patients (Table 1). Four patients had multiple injuries, two of whom had injury of the ipsilateral limb.

\section{Surgical technique}

Patient positioning, surgical incision, and superficial exposure are similar to that described by Weaver-Dunn [9]. The acromial attachment of the coracoacromial ligament was released from the acromion with a small piece of bone. Two heavy nonabsorbable sutures were placed in the ligament. In the clavicle, a gliding hole was made through the caudal cortex opposite to the base of the coracoid process, with two small drill holes in the cranial cortex. The sutures in the coracoacromial ligament were passed through the gliding hole and out through the two small drill holes and left untied. The acromioclavicular joint was held in reduced position using an acromioclavicular tension band (Fig. 1A-C). Then the sutures through the ligament were tied, thereby placing the small bone fragment in the ligament end in the clavicle's medullary canal. The tied suture ends were used to reattach the acromioclavicular capsule. The capsule was rarely well-defined, so identification of a stout tissue layer attached to the acromion laterally and including a combination of capsule, periosteum, and fascia, was important. The remaining portion of the fascia and aponeurosis was imbricated over the top of the clavicle. 
Table 1 Patient data $(n=12)$

\begin{tabular}{|c|c|c|c|c|c|c|c|}
\hline \multicolumn{4}{|c|}{ Patients } & \multirow{2}{*}{$\begin{array}{l}\text { Time from injury } \\
\text { to surgery (months) }\end{array}$} & \multirow{2}{*}{$\begin{array}{l}\text { Mechanism } \\
\text { of injury }\end{array}$} & \multirow{2}{*}{$\begin{array}{l}\text { Follow-up } \\
\text { (months) }\end{array}$} & \multirow{2}{*}{$\begin{array}{l}\text { Total UCLA score [5] } \\
\text { at follow-up }\end{array}$} \\
\hline No. & Age & Gender & $\begin{array}{l}\text { Dominant } \\
\text { shoulder }\end{array}$ & & & & \\
\hline 1 & 36 & $\mathrm{M}$ & + & 3 & Traffic accident & 52 & 20 \\
\hline 2 & 23 & M & - & 5 & Sport & 60 & 15 \\
\hline 3 & 29 & M & + & 4 & Sport & 58 & 20 \\
\hline 4 & 24 & $\mathrm{~F}$ & + & 3 & Sport & 47 & 20 \\
\hline 5 & 46 & M & + & 11 & Fall & 50 & 12 \\
\hline 6 & 27 & M & + & 3 & Sport & 41 & 19 \\
\hline 7 & 32 & $\mathrm{~F}$ & - & 5 & Traffic accident & 38 & 16 \\
\hline 8 & 28 & M & + & 3 & Sport & 43 & 19 \\
\hline 9 & 37 & M & + & 6 & Fall & 36 & 15 \\
\hline 10 & 34 & $\mathrm{Fm}$ & + & 4 & Fall & 24 & 20 \\
\hline 11 & 25 & M & - & 4 & Sport & 30 & 20 \\
\hline 12 & 48 & M & + & 3 & Fall & 18 & 20 \\
\hline
\end{tabular}

Postoperatively, the arm was supported in a sling for 6 weeks, but after 2 weeks, the patient was allowed to use the arm for daily activities at waist level. The tension band was removed 4 months after surgery. Athletes were not permitted to return to sport without restriction until full strength and range of motion were recovered. This usually occured by $5-6$ months after surgery.

\section{Results}

Patients were evaluated clinically and radiologically at postoperative visits using a modification of the UCLA rating scale (Table 2) [5]. At final follow-up, 11 patients maintained a normal distance between the coracoid and the clavicle. Only in one patient was the clavicle slightly subluxated 10 weeks after surgery. All patients felt that the strength of their shoulder was improved after surgery. Forward elevation against resistance was assessed comparing two shoulders, and in eight patients we found normal strength. The range of movement was compared with uninvolved shoulder and with the preoperative status of the involved shoulder. Eight patients had full range, and an additional three patients with restricted movement preoperatively had improved motion. Thus, improved or normal range of movement was present in 11 patients. Eight patients were without pain, three had pain with moderate activity, and one with mild activity. There were three patients with complications: superficial infection in one, hematoma in one, and loosening of fixation with subluxed clavicle in one. Overall, eight patients rated their shoulder function as excellent, three as good, and one as fair.

\section{Discussion}

There are some contradictory opinions about the definition of chronic complete acromioclavicular dislocation. Previously it was thought to be associated with a complete disruption of the acromioclavicular joint and of the coracoacromial ligament. Recently it has been reported [3] that chronic complete acromioclavicular dislocation is characterized by anteroposterior and super-
Table 2 Modified UCLA acromioclavicular rating scale ${ }^{a}$

\begin{tabular}{|c|c|}
\hline Category & Points \\
\hline \multicolumn{2}{|l|}{ Maintenance of reduction } \\
\hline $\begin{array}{l}\text { Reduced } \\
\text { Subluxed } \\
\text { Dislocated }\end{array}$ & $\begin{array}{l}4 \\
2 \\
0\end{array}$ \\
\hline \multicolumn{2}{|l|}{ Range of motion } \\
\hline $\begin{array}{l}\text { Full } \\
\text { Improved from preoperative } \\
\text { No change from preoperative }\end{array}$ & $\begin{array}{l}2 \\
1 \\
0\end{array}$ \\
\hline \multicolumn{2}{|l|}{ Strength } \\
\hline $\begin{array}{l}\text { Normal } \\
\text { Improved from preoperative } \\
\text { Unimproved from preoperative }\end{array}$ & $\begin{array}{l}2 \\
1 \\
0\end{array}$ \\
\hline \multicolumn{2}{|l|}{ Pain } \\
\hline $\begin{array}{l}\text { None } \\
\text { With strenuous activity } \\
\text { With moderate activity } \\
\text { With mild activity } \\
\text { All the time }\end{array}$ & $\begin{array}{l}4 \\
3 \\
2 \\
1 \\
0\end{array}$ \\
\hline \multicolumn{2}{|l|}{ Weakness } \\
\hline $\begin{array}{l}\text { None } \\
\text { With strenuous activity } \\
\text { All the time }\end{array}$ & $\begin{array}{l}2 \\
1 \\
0\end{array}$ \\
\hline \multicolumn{2}{|l|}{ Change in occupation } \\
\hline $\begin{array}{l}\text { Same or more strenuous } \\
\text { Less strenuous }\end{array}$ & $\begin{array}{l}2 \\
0\end{array}$ \\
\hline \multicolumn{2}{|l|}{ Patient satisfaction } \\
\hline $\begin{array}{l}\text { Yes } \\
\text { No }\end{array}$ & $\begin{array}{l}2 \\
0\end{array}$ \\
\hline \multicolumn{2}{|l|}{ Complication } \\
\hline $\begin{array}{l}\text { None } \\
\text { Minor/resolved } \\
\text { Major/affected outcome }\end{array}$ & $\begin{array}{l}2 \\
1 \\
0\end{array}$ \\
\hline \multicolumn{2}{|l|}{ Results } \\
\hline $\begin{array}{l}\text { Excellent } \\
\text { Good } \\
\text { Fair } \\
\text { Poor }\end{array}$ & $\begin{array}{r}18-20 \\
15-17 \\
12-14 \\
\leq 11\end{array}$ \\
\hline
\end{tabular}

${ }^{\text {a }}$ See Guy et al [5] 

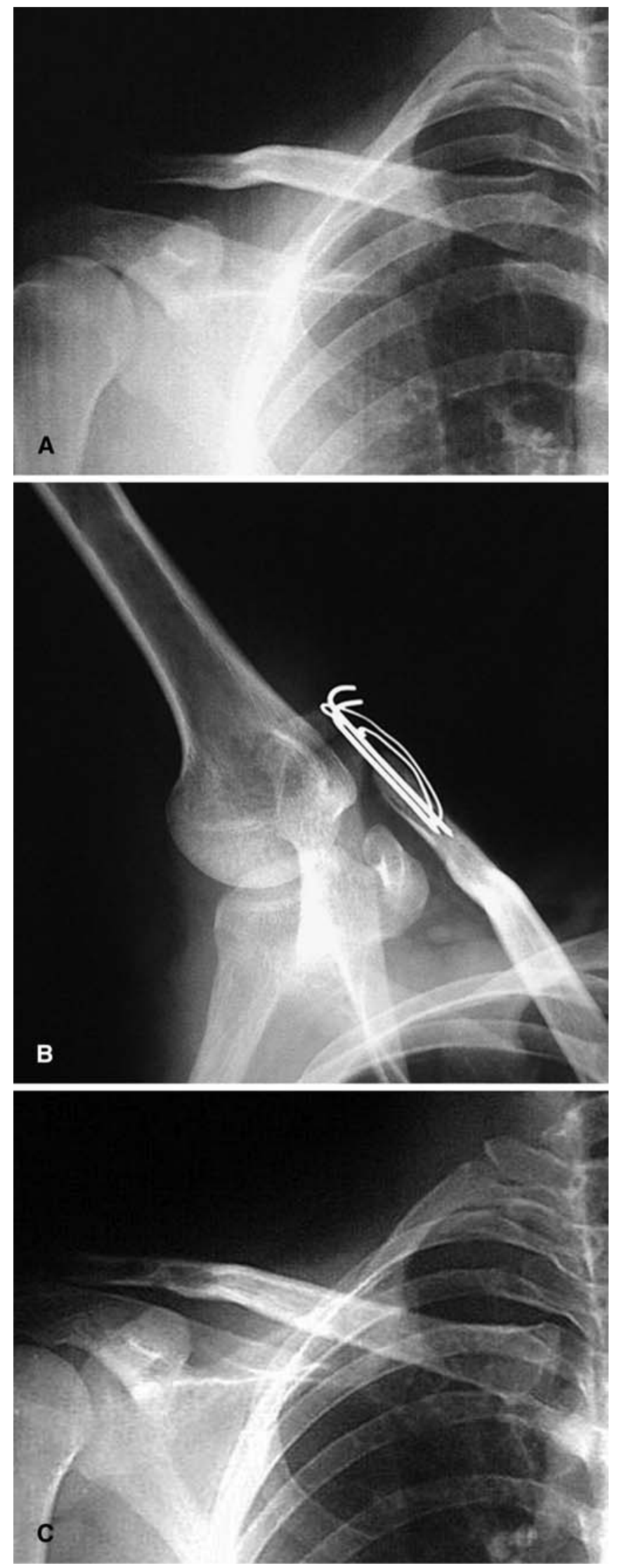

oinferior acromioclavicular instability in addition to articular degeneration.

Reported surgical procedures for chronic, complete acromioclavicular dislocations are numerous; many only of historical interest. Currently most surgical procedures involve some combination of coracoclavicular and acromioclavicular fixation with or without distal clavicle excision. Methods of coracoclavicular fixation include coracoclavicular screws, absorbable and nonabsorbable coracoclavicular sutures, and suture anchors. Acromioclavicular fixation options include acromioclavicular wires and screws. Imbrication of the deltotrapezius aponeurosis is an important part of the reconstruction.

Some authors [6, 8] describe resection arthroplasty of the distal clavicle. However, this procedure fails to address the concomitant problem of instability associated with disruption of the coracoclavicular ligament and injuries of the deltoid and trapezius muscles. The main goal in our study was restitution of static and dynamic stabilizers of the acromioclavicular joint by coracoclavicular and acromioclavicular ligament reconstruction, joint debridement, and imbrication of the deltotrapezius aponeurosis over the top of the clavicle. Some authors [9] used the coracoacromial ligament in reconstruction of the acromioclavicular joint in 15 patients, only three of whom had a chronic injury to the acromioclavicular joint. They did not use internal fixation to protect their reconstruction and had a $20 \%$ incidence of recurrent deformity and one complete failure that occurred 16 months after surgery. Guy et al [5] used a coracoclavicular lag screw to protect the reconstruction and reported that the lag screw was broken in two of 23 patients.

In this study, the reconstruction was protected by a tension band between the acromion and the clavicle, which maintained reduction in the horizontal as well as vertical plane. The purpose of the tension band is to temporarily stabilize the clavicle in its reduced position in relation to the coracoid process and to protect the transferred coracoacromial ligament from stretching or rupture during the postoperative healing period.

At the final follow-up, 11 patients had maintained their operative reduction. Overall, eight patients rated their results as excellent, three as good, and one as fair. No patient thought they had a poor result. All patients with excellent and good results had their reconstruction within an average of 4 months after injury. The patient with a fair result had an extended interval from injury to reconstruction (11 months).

The advantages of this technique are: (1) restitution of static and dynamic stabilizers of acromioclavicular joint by reconstruction of ligaments and deltotrapezius aponeurosis; (2) replaced coracoacromial ligaments substitute for the strong coracoclavicular ligaments, reproducing a

Figure 1 A Stress radiograph with complete acromioclavicular dislocation of the right shoulder. B Four months postoperative radiographs showing the temporarily used tension band. C Two years postoperative radiograph of right shoulder after removal of the temporary tension band 
construction that closely resembles a physiologically and anatomically normal state; (3) there is no fear of rupture if transplanted tendon or wire is used.

\section{References}

1. Bino S, Fujita S (1969) The treatment of acromioclavicular dislocation. Orthop Surg (Tokyo) 20:583

2. Bosworth BM (1941) Acromioclavicular separation. A new method of repair. Surg Gynecol Obstet 73:866

3. Galatz LM, Barrett S, Williams GR Jr (2001) Injuries to the acromioclavicular joint. Sports medicine and arthroscopy review 9: 44-51

4. Gurd FB (1941) The treatment of complete dislocation of the outer end of the clavicle; A hitherto undescribed operation. Ann Surg 113:1094
5. Guy DK, Wirth MA, Griffin JL, Rockwood CA (1998) Reconstruction of chronic and complete dislocation of the acromioclavicular joint. Clin Orthop 347:138-149

6. Lazcano MA, Anzel SH, Kelly PJ (1961) Complete dislocation and subluxation of the acromioclavicular joint. J Bone Joint Surg [Am] 43:379-391

7. Neviaser JS (1952) Acromioclavicular dislocation treated by transference of the coraco-acromial ligament: A long-term follow-up in a series of 112 cases. Arch Surg 64:292

8. Sage FP, Salvatore JE (1983) Injuries of the acromioclavicular joint. A study of results in ninety-six patients. South Med J 56:486-495

9. Weaver JK, Dunn HK (1972) Treatment of acromioclavicular injuries: Especially complete acromioclavicular separation. J Bone Joint Surg [Am] 54:1187-1194 